\title{
EXPERIMENTAL MODELS OF DIABETES MELLITUS
}

Jelena Pantic ${ }^{1}$, Vladislav Volarevic ${ }^{1}$, Aleksandar Djukic ${ }^{1}$

${ }^{1}$ Faculty of Medicine, University of Kragujevac

\section{EKSPERIMENTALNI MODELI DIJABETES MELITUSA}

\author{
Jelena Pantić ${ }^{1}$, Vladislav Volarević ${ }^{1}$, Aleksandar Đukić ${ }^{1}$
}

${ }^{1}$ Medicinski fakultet, Univerzitet u Kragujevcu

\begin{abstract}
APSTRAKT
Early studies on pancreatectomised dogs confirmed the central role of the pancreas in the homeostasis of glycemia and resulted in the discovery of insulin. Today, hundreds of different animal models are used in experimental studies of diabetes. The aim of this review is to present experimental models of type 1 and type 2 diabetes. In preparing for this review, we searched the electronic databases Medline, Highwire, and Hinari.

The majority of the experiments are conducted on rodent models (mice and rats). Selective inbreeding resulted in the development of numerous models with pathogenic characteristics and the manifestation of type 1 and 2 diabetes and the related phenotypes of obesity and insulin resistance. In addition to analyzing the pathogenic mechanisms of the disease and its complications, these models are used to evaluate new treatment solutions as well as the transplantation of beta cells and disease prevention. New animal models have been created using techniques based in molecular biology and genetic engineering: transgenic, knockout and tissue-specific knockout models. These are very powerful methods, which may lead to exciting results in the future.
\end{abstract}

Key words: animal models, experimental diabetes, mouse, rat

\section{SAŽETAK}

Prve studije radene na psima kojima je prethodno $u k$ lonjen pankreas potvrdile su centralnu ulogu pankreasa $u$ homeostazi glikemije $i$ doprineli otkriću insulina. Danas, veliki broj različitih eksperimentalnih modela se koristi $u$ istraživanjima u oblasti dijabetesa. Cilj ovog revijskog rada je da predstavi neke od ovih modela, koristeći kao literaturu originalne i revijske radove elektronskih baza Medline, Highwire i Hinari.

Većina laboratorija koristi selektivnim inbridingom dobijene miševe i pacove, kao i transgene i nokaut životinje dobijene genetskim inženjeringom, koje zbog svojih karakteristika (npr. gojaznost, rezistencija na insulin) predstavljaju idealne eksperimentalne modele za dijabetes tip 1 ili 2. Ovi eksperimentalni modeli koriste se kako za ispitivanje patogeneze dijabetesa tako i za ispitivanja novih terapijskih sredstava $u$ lečenju šećerne bolesti.

Ključne reči: animalni modeli, eksperimentalni dijabetes, miš, pacov

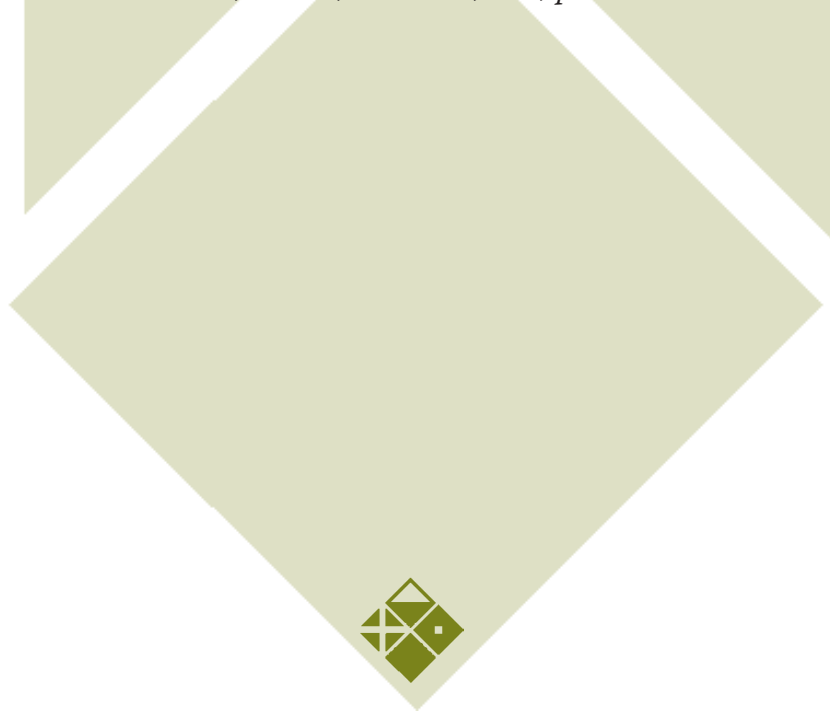




\section{INTRODUCTION}

Since 1880, when von Mering and Minkowski removed the pancreas from a dog displaying symptoms of diabetes mellitus (1), many experiments have been conducted on mice, rats, rabbits, and dogs, which were all used as experimental models for this disease.

The rodents (mice and rats) are most frequently used in laboratory research of type 1 and type 2 diabetes because they are biologically and genetically similar to people, their reproductive potential is high, their life span is short, and they are cheap and easy to handle (1). The main drawback of these models is that sometimes they are unable to successfully simulate pathological processes occurring in humans; in those situations, the use of cats, dogs, pigs or primates is justifiable.

Models of experimental diabetes are:

1. induced (experimental)

2. spontaneous (genetically induced) or

3. transgenic and knock-out models (resulting from genetic engineering).

Hyperglycemia is induced by:

1. surgical method (partial or total pancreatectomy)

2. non-surgical method (using a diabetogenic toxin in experimental animals) (Table 1) (2).

\section{MATERIALS AND METHODS}

We searched the electronic databases Medline, Highwire, and Hinari. Selected papers, both original and review, have been summarized and cited with regard to their scientific relevance for this research field.

\section{EXPERIMENTAL MODELS OF TYPE 1 DIABETES MELLITUS}

\section{A) Induced models}

Multiple low-dose streptozotocin-induced diabetes

Streptozotocin (STZ) is a derivative of nitrosourea that has been isolated from Streptomyces achromogenes. It is a strong alkylating agent that affects glucose trans-

\begin{tabular}{|l|l|}
\multicolumn{1}{|l}{ Toxin } & Diabetogenic effect \\
\hline Streptozotocin & Hyperglycemia, glucose intolerance \\
\hline Alloxan & Hyperglycemia, glucose intolerance \\
\hline Chlorozotocin & Hyperglycemia, glucose intolerance \\
\hline Dithizone & Hyperglycemia, glucose intolerance \\
\hline Vacor & Hyperglycemia \\
\hline Oxine & Hyperglycemia \\
\hline Methylnitrosurea & Glucose intolerance \\
\hline Cyproheptadine & Glucose intolerance \\
\hline
\end{tabular}

Table 1. Toxins with diabetogenic effect port (the role of glucokinase) and induces numerous lesions in the beta-cell DNA chain (3-5). It can selectively bind to glucose-transport protein 2 (GLUT2), which is predominantly expressed on the membranes of pancreatic beta-cells (3).

Toxicity of the streptozotocin on beta-cells is complex and includes genetic and non-genetic mechanisms (6). $\mathrm{Ni}$ tric oxide (NO) and other free radicals influenced by streptozotocin result in spontaneous lesions of the DNA chain (7). Damaged DNA chains activate poly-(ADP-ribose) polymerase (PARP) as a reparatory mechanism, which in case of over-activation may have proapoptotic effects (8). PARP knockout mice were shown to be resistant for streptozotocin-induced diabetes (8).

In addition, the toxicity of streptozotocin is associated with a drastic decrease of insulin reserves within beta cells, resulting from the fast catabolism of nicotinamide-adenine-dinucleotide+ (NAD+), a substrate for PARP activation (9). Decrease of NAD+ and ATP+ provokes significant depletion of insulin secretion as well as other basic processes inside the cell. While excessive activation of PARP represents a proapoptotic stimulus, the reduction of necessary cell energy results in cellular necrotic death.

A single high dose of streptozotocin provokes diabetes in rodents, possibly as a result of the direct toxic effect. Multiple low-dose streptozotocin-induced diabetes (when streptozotocin is administered in lower doses $(40 \mathrm{mg} / \mathrm{kg})$ during five consecutive days) is an experimental model of type 1 diabetes and immune-mediated insulitis and is widely used for studying the immunological background of this disease (10).

\section{Partial pancreatectomy}

The partially pancreatectomised rat was one of the first experimental models of diabetes (11). The surgical removal of $90 \%$ of the pancreatic tissue resulted in a slow development of hyperglycemia over the course of 12 weeks to 20 months (12). The period of post-surgical euglycemia is followed by the development of chronic hyperglycemia as a consequence of a further failure of the remaining beta cells.

The first stage of disease refers to glucose intolerance followed by a compensatory hyper-function of beta-cells, the exhaustion of the remaining beta cells and their further breakdown 14 weeks after surgery (12). Altered beta cell gene expression is associated with a decreased production of islet amylin polypeptide (IAPP), transcription factors, ionic canals and pumps, including GLUT2, glucokinase, mitochondrial glycerophosphate dehydrogenase (mGPD) and pyruvate carboxylase (13). A reduction of insulin secretion follows even in conditions of high concentrations of glucose and even after application of insulin secretagogues (14).

Histopathological findings demonstrate hypertrophy and fibrosis of pancreatic islets related to the level of hyperglycemia (13). Insulitis, demonstrated as the infiltration of inflammatory cells, may be depressed, thus slowing down the process of cell degeneration (15). 


\section{B) Spontaneous models}

The most frequently used spontaneous models of type 1 diabetes are the non-obese diabetic (NOD) mouse and the bio-breeding $(\mathrm{BB})$ rat. These two strains are the result of laboratory inbreeding (keen cross-breeding) of a large number of generations; they develop the disease spontaneously, similar to type 1 human diabetes.

\section{NOD mouse}

The NOD mouse is an inbred, homozygous strain discovered in 1974 in Shionogi Research Laboratories in Osaka, Japan. It was a result of keen cross-breeding from normoglycemic strains used for cataract research (Jcl-ICR mouse) and bred in sterile conditions, free from species-specific pathogens (16). The NOD mouse developed insulitis detectable by electronic microscopy after 2 weeks, and within 4-5 weeks it becomes visible under standard microscopy (17). The infiltration is mainly characterized by the presence of a large number of CD 4+ T lymphocytes, while CD 8+ T and B lymphocytes, as well as NK cells are not so numerous (18). Insulitis is progressive and accompanied by the destruction of beta cells and a decrease of insulin levels in serum. In contrast to the disease in the human population, these strains have mild ketoacidosis and can survive for weeks without insulin substitution (1). Incidence of this disease differs between genders (90\% among females and $60 \%$ among males) (1).

Similar to the human population, the main autoantigenes in pathogenesis of this disease, recognized by secreted antibodies, are insulin, glutamic acid decarboxylase (GAD), and tyrosine phosphatase (ICA512, known as IA-2) (19).

The genetic background of diabetes in this model highlights the role of a major histocompatibile complex (MHC) class II gene that codes for molecule I-A $\mathrm{A}^{\mathrm{7}}(20-21)$. The expression of $\mathrm{MHC}$ molecule class I refers to proteins $\mathrm{K}^{\mathrm{d}}$ and $\mathrm{D}^{\mathrm{b}}(22)$. An alteration of INS gene expression, controlling the expression of insulin in the thymus and the deletion of $\mathrm{T}$ reactive lymphocytes in the case of central tolerance, is related to an initiation of the autoimmune process (22). A similar situation is observed with the cytotoxic T lymphocyte antigen 4 (CTLA-4) gene, which codes for a negative signal molecule for CD8+ T cells and controls the activation and expansion of $\mathrm{T}$ lymphocytes (22). The protein tyrosine phosphatase non-receptor type 22 (PTPN22) gene, associated with autoimmune diabetes, codes for tyrosine phosphatase (LYP or PEP), a negative regulator of T cells (22). Variations of genes coding for IL2 and CD25 FoxP3 $^{+}$that a key role in maintaining immune homeostasis are common for both human and NOD mice (22).

\section{BB rat}

The BB rat was discovered in 1974 within the commercial campaign of the Company Bio Breeding Laboratories, Ottawa. It develops diabetes spontaneously (decrease of body weight, polyuria, polydipsia, hyperglycemia and insulopenia) during puberty-approximately the $12^{\text {th }}$ week of life (1). Similar to the human population, the BB rat develops serious/fatal ketoacidosis unless insulin substitution is administered. (1)
The disorder is autoimmune, and insulitis is characterized by the infiltration of $\mathrm{T}$ lymphocytes, B lymphocytes, macrophages and NK cells (23). Typical for this species is extreme lymphopenia associated with a decreased number of $\mathrm{T}$ lymphocytes with an elevated expression of ADP-ribosyltransferase 2 (ART2); this has not been registered in the human population (24). A transfusion of histocompatible T ART2+ lymphocytes prevents spontaneous hyperglycemia in this model (24).

Recent studies show that $\mathrm{BB}$ rat diabetic syndrome is a complex, polygenic disease that may share additional susceptibility genes aside from MHC class II with human type 1 diabetes (25). The expression of two main susceptibility genes is responsible for the development of diabetes in the $\mathrm{BB}$ rat: MHC (RT1) class II $\mathrm{u}$ haplotype (Iddm1) and the Gimap5 (GTPase immunity associated protein family member 5) gene, a key genetic factor for lymphopenia in spontaneous BB rat diabetes (Iddm2) (25).

\section{EXPERIMENTAL MODELS OF TYPE 2 DIABETES}

\section{A) Induced models}

\section{C57BL/6J mouse fed a high-fat diet}

This model was originally introduced by Surwit et al. in 1988 as a robust model of impaired glucose tolerance (IGT) and early type 2 diabetes (26). C57BL/6J mice fed a high-fat diet ( $58 \%$ energy by fat, a "Western diet") developed hyperglycemia, hyperinsulinemia, hyperlipidemia and increased adiposity (27). High-fat diet results in insulin resistance with compensatory hyperinsulinemia. After one week on the diet, baseline plasma glucose and insulin are significantly elevated and intravenous glucose tolerance test (IVGTT) shows reduced glucose elimination and impaired insulin secretion (28). The model thus shows two important pathophysiological characteristics for impaired glucose tolerance (IGT) and type 2 diabetes: insulin resistance and islet dysfunction.

In this model, the weight gain is due primarily to an increase in mesenteric adiposity. In high-fat diet-fed mice, energy intake is higher and metabolic efficiency index is lower compared to normal diet-fed mice (28). Despite obesity, plasma leptin levels are significantly lower than in the control group in the absence of hyperphagia (29). Increased serum lipid levels develop concomitantly with the development of hyperglycemia, thus deteriorating insulin resistance and producing lipid deposits in non-adipose cells, including beta cells and skeletal muscle cells (30). Microscopically, a high-fat diet induces hypertrophy of pancreatic islets (31)

This model is suitable for examining novel therapeutic interventions. The dipeptidyl peptidase-IV (DPP-IV) inhibitor is efficient in improving glucose tolerance and insulin secretion in the high-fat diet-fed mouse model (28).

Partial pancreatectomy as a surgical method of inducing diabetes was described above. 


\section{B) Spontaneous models}

\section{Goto Kakizaki Rat}

The Goto Kakizaki (GK) rat is skinny, diabetic rat developed in Japan in 1975 from Wistar species (6). Both insulin resistance and impaired insulin secretion are present in this model (32). GK rats have a decreased numbers of beta cells at birth, which is probably the consequence of their apoptosis during embryonic development (16-18 day). However, GK rats are still normoglycemic and without marked changes in islet morphology at birth (33). The characteristics of diabetes type 2 in this model are mild hyperglycemia $(9 \mathrm{mmol} / \mathrm{l})$ in the fourth week and the increase of basal insulin secretion and insulin resistance followed by a decrease in glucose tolerance (34). GK rats are resistant to food intake restrictions (35).

Starting from the $8^{\text {th }}$ week, insulin islets show signs of fibrosis with a marked elevation of hyperglycemia (36). In addition, the expression of CD38 and GLUT2 proteins is reduced in GK islets (37-38). Microscopically, numerous macrophages (major histocompatibility complex class $\mathrm{II}^{+}$and $\mathrm{CD}^{+}$) and granulocytes were found in and around pancreatic islets (39). Elevated islet IL-1 $\beta$ activity in GK rat promotes cytokine and chemokine expression, leading to the recruitment of innate immune cells (40). Treatment of GK rats with IL-1 receptor antagonists decreases hyperglycemia, reduces the proinsulin/ insulin ratio and improves insulin sensitivity (40).

The most important factor for the disorder of insulin secretion is the dysfunction of glucose metabolism connected with a deficiency of enzymes that control oxidative glycolysis (6). The GK rat develops some features that can be compared with the complications of diabetes seen in humans (1).

\section{Zucker Fatty and Zucker Fatty Diabetic Rat}

The Zucker Fatty (ZF) rat has a defect of a gene that codes for leptin receptors ( $\mathrm{fa} / \mathrm{fa}$ ), resulting in the development of obesity and hypertension with associated renal and cardiovascular disease (6). The Zucker Fatty Diabetic Rat (ZDF) has the identical genetic mutation and, additionally, a mutation which leads to the spontaneous development of hyperglycemia in males during the $7^{\text {th }}-10^{\text {th }}$ week (41). The females become hyperglycemic only after high-fat diet, and it is supposed that this additional mutation is expressed in beta cells (42).

Leptin suppresses insulin secretion and controls food intake. The fa/fa mutation of the leptin receptor results in insulin resistance with severe glucose intolerance (6). ZF and ZDF rats are hyperphagic due to the reduction in leptin signalling that results in obesity (6). These animals, in adulthood, become extremely dislipemic with increased concentration of free fatty acids, cholesterol, and triglycerides in plasma with a consequent development of diabetes mellitus complications (cardiovascular, renal, and peripheral neuropathy) $(6,43-44)$.

Pancreatic islets in adults show increased beta cell activity, with marked characteristics of a prediabetic state (6). After the onset of diabetes, pancreatic islets become irreg- ular as a result of hyperplasia, hypertrophy and infiltration of inflammatory cells (45). An almost complete absence of beta cells was detected by the $14^{\text {th }}$ week of age (45).

Reduced expression of mGDP and pyruvate carboxylase activity was noticed in this model (46).

\section{Otsuka Long Evans Tokushima Fatty Rat}

The Otsuka Long Evans Tokushima Fatty Rat (OLETF) is derived by inbreeding from the glucose-intolerant LongEvans colony of rats (47). These animals develop hyperglycemia slowly, by 40 weeks of age, with greater incidence in males than in females (1). Adult animals are mildly obese and hyperglycemic, with increased appetite and renal glomerulosclerosis. These changes are the result of a deletion of the gene for cholecystokinin 1 receptors. Diet and exercise prevent type 2 diabetes in this model (48).

Histopathologic changes inside the islets during the $8^{\text {th }}$ $10^{\text {th }}$ week show an infiltration of inflammatory cells followed by tissue damage. Beta cell hyperplasia and proliferation occur between the $20^{\text {th }}$ and $40^{\text {th }}$ weeks, while atrophy and fibrosis of the islets start after the $40^{\text {th }}$ week (47). From the $72^{\text {nd }}$ week, inflammatory cytokines (tumour necrosis factor(TNF-), interleukin-1 $\beta$ (IL-1 $\beta$ ) and interleukin-6 (IL-6)) are detectable by immunohistochemical method (49).

\section{Psammomys obesus}

The Psammomys obesus is rat from North America and the Middle East. It usually feeds on a low-calorie diet and demonstrates the strong effect of a high-calorie diet by developing hyperglycemia within 4-7 days (6).

Pathogenesis of the disorders goes through four typical stages: normoglycemia and normoinsulinemia, normoglycemia with hyperinsulinemia (indicating insulin resistance), hyperglycemia with hyperinsulinemia, and hyperglycemia with hypoinsulinemia (50). The last stage is characterized by marked apoptosis and a reduction of beta cell mass (51). Returning to a low-calorie diet results in the recovery of beta cells, indicating that the irreversible loss of beta cell mass is a late event (52).

\section{TRANSGENIC AND KNOCKOUT MODELS OF DIABETES MELLITUS}

In experimental diabetes, numerous transgenic and knockout models are being used. These models have been created by genetic manipulations using either transgene insertion and/or targeted gene-deletion approaches.

Still, these techniques have some limitations. Some homozygotes may die in the womb, which makes studies in adults impossible. Several genes could function differently during embryogenesis and in adulthood. Finally, some models' gene expression is altered in soft tissues, and therefore it is impossible to analyze their function in the desired tissue. Tissue-specific knockout models for diabetes, in which the gene being studied is only knocked out in specific tissues, were created to address this issue. 


\begin{tabular}{|l|l|l|}
\hline Mouse/rat model & Phenotype & Reference \\
\hline IR +/- & Mild insulin resistance & 53,54 \\
\hline IR -/- & Severe hyperglycemia, neonatal death from ketoacidosis & 54 \\
\hline IRS-1 -/- & $\begin{array}{l}\text { Mild insulin resistance, normoglycemia, } \\
\text { elevated serume triglycerides, hypertension, growth retardation }\end{array}$ & 55 \\
\hline IRS-2 -/- & Insulin resistance, hyperglycemia, reduced beta-cell mass & 56 \\
\hline IRS-1 -/- IRS-3 -/- & Hyperglycemia, lipatrophy, decreased plasma levels of leptin, hyperinsulinemia & 57 \\
\hline IRS-1+/- IR +/- & Insulin resistance, beta-cell hyperplasia & 58 \\
\hline GK -/- & Hyperglycemia, perinatal death & 59 \\
\hline GK +/- & Glucose intolerance & 59 \\
\hline GLUT4 -/- & $\begin{array}{l}\text { Mild changes in glucose hemostasis, growth retardation, reduction of fat, } \\
\text { cardiac hypertrophy }\end{array}$ & 60 \\
\hline PPAR $+/-$ & Mild insulin resistance & 61 \\
\hline PPAR $2-/-$ & Insulin resistance, reduction of white adipose tissue & 62 \\
\hline PPAR $\alpha /-$ & No phenotypical defect without pharmacological intervention & 63 \\
\hline hIAPP +/+ rat & $\begin{array}{l}\text { Decreased proliferation and increased apoptosis of beta cell, } \\
\text { hyaline replacement of islet cells }\end{array}$ & 64 \\
\hline
\end{tabular}

The first knockout models of insulin resistance aimed at the disruption of major molecules in insulin receptor (IR) signaling. Heterozygous IR knockout mice show $50 \%$ of IR expression, which is sufficient for the maintenance of physiological blood glucose contentrations (53). In contrast, homozygous IR-deficient mice rapidly develop diabetic ketoacidosis and die within 3-7 days after birth, showing the central role of IR in glucose metabolism (54). Aside from IR knockouts, various molecules of the signal transduction pathway initiated by IR have been disrupted, such as insulin receptor substrates (IRS-1, IRS-2, IRS-3) (55-58). Insulin resistance and insulin secretory defects have also been presented by a generation of mice deficient in beta cell glucokinase (GK). The heterozygous beta cell GK knockout mouse is characterised by decreased insulin secretion in response to glucose (59). The homozygous knockout mouse model with a disrupted gene for the glucose transporter 4 (GLUT4), which mediates glucose transport in muscle and adipose tissue in response to insulin, is characterised by mild changes in glucose hemostasis, growth retardation, reduction of fat and cardiac hypertrophy (60). The important physiological role of peroxisome proliferator-activator receptors (PPAR $\alpha$ and PPAR $\gamma$ ) was deduced from findings identifying the PPARs as primary targets of tiasolidinedione insulin sensitizers and fibrates that have been used in the successful treatment of diabetes and dyslipidemia. Diverse knockout models have been created to study the function of single PPARs isoforms (6163). Similar to other mouse models, a transgenic human islet amyloid polypeptide-expressing rat has been recently developed (64). This model shows pancreatic amyloidosis, insulin resistance, and reduced $\beta$-cell mass with resulting hyperglycemia (64). Some of the transgenic/knockout and tissue-specific knockout models are presented in Table 2.

\section{REFERENCES}

1. Rees DA, Alcolado JC. Animal models of diabetes mellitus. Diabetic medicine 2005; 22: 359-370.

2. Wilson GL, LeDoux SP. The Role of Chemicals in the Etiology of Diabetes Mellitus. Toxicologic Pathology 1989; 17(2): 357.

3. Wang Z, Gleichmann H. GLUT2 in pancreatic islets: crucial target molecule in diabetes induced with multiple lowdoses of streptozotocin in mice. Diabetes 1998; 47: 50-56.

4. Zahner D, MalaisseWJ. Kinetic behaviour of liver glucokinase in diabetes, I, Alteration in streptozotocindiabetic rats. Diabetes Res 1990; 14: 101-108.

5. Bolzan AD, Bianchi MS. Genotoxicity of streptozotocin. Mutat Res 2002; 512: 121-134.

6. Nugent DA, Smith DM, Jones HB. A Rewiew of Islet of Langerhans Degeneration in Rodent Models of Type 2 Diabetes. Toxicologic Pathology 2008; 36(4): 529-551.

7. Wada R, Yagihasi S. Nitric oxide generation and poly (ADP ribose) polymerase activation precede beta-cell death in rats with a single high-dose injection of streptozotocin. Virchows Arch 2004; 444: 375-82.

8. Peiper AA, Brat DJ, Krug DK, Watkins CC, Gupta A, BlackshawB S, Verma A, Wang ZQ, Snyder SH. Poly(ADP-ribose) polymerase-deficient mice are protected from streptozotocin-induced diabetes. Proc Natl Acad Sci USA 1999; 96: 3059-62.

9. Cardinal JW, Allan DJ, Cameron DR. Poly(ADP-ribose) polymerase activation determines strain sensitivity to streptozotocin-induced $\beta$ cell death in inbred mice. J Mol Endocrinol 1999; 22: 65-70.

10. Mensah-Brown EP, Stosic Grujicic S, Maksimovic D, Jasima A, Lukic ML. Downregulation of apoptosis in the target tissue prevents low-dose streptozotocin-induced autoimmune diabetes. Mol Immunol 2002; 38: 941-946. 
11. Lewis JT, Foglia VG, Rodriguez RR. The effects of steroids on the incidence of diabetes in rats after subtotal pancreatectomy. Endocrinology 1950; 46: 111-21.

12. Yomemura Y, Takashima T, Matsuki N, Hagino S, Sawa T, Takashima S, Miwa K, Miyazaki I. The pathogenesis of diabetes produced by subtotal pancreatectomyp, with special reference to the cell kinetics of the islet cells. Nippon Geka Gakkai Zasshi 1984; 85: 356-62.

13. Laybutt DR, Glandt M, Xu G, Ahn YB, Trivedi N, Bonner-Weir S, Weir GC. Critical reduction in beta-cell mass results in two distinct outcomes over time. Adaption with impaired glucose tolerance or decompensated diabetes. J Biol Chem 2003; 278: 2997-3005.

14. Rossetti L, Shulman GI, Zawalich W, DeFronzo RA. Effect of chronic hyperglycaemia on in vivo insulin secretion in partially pancreatectomized rat.J Clin Invest 1887; 80: 1037-1044.

15. Lampeter EF, Tubes M, Klemens C, Brocker U, Friemann J, Kolb-Bachofen V, Gries FA, Kolb H. Insulitis and islet-cell antibody formation in rats with experimentally reduced beta-cell mass. Diabetologia 1995; 38: 1397-04.

16. Hanafusa T, Miyagawa J, Nakajima H, Tomita K, Kuwajima M, Matsuzawa Y, Tarui S. The NOD mouse. Diabetes Research and Clinical Practice 1994; 24: 307-311.

17. Fijino-Kurihara H, Fujita H, Hakura \$, Nonaka K, Tarui S. Morphological aspects of non-obese diabetic (NOD) mice. Virchows Arch 1885; 149: 107-120.

18. Miyazaki A, Hanafusa T, Yamada K. Predominance of T lymphocytes in pancreatic islets and spleen of prediabetic non-obese diabetic (NOD) mice: a longitudinal study. Clin Exp Immunol 1985; 60: 622-630.

19. Wong FS, Janeway CA Jr. Insulin-dependent diabetes mellitus and its animal models. Curr Opin in Immunol 1999; 11: 643-647.

20. Murphy K, Travers P, Walport M. Janeways Immunobiology. Garland Science 2008; Chapter 14: 600-609.

21. Serreze DV, Leiter EH. Genetic and pathogenic basis of autoimmune diabetes in NOD mice. Curr Opin in Immunol 1994; 6: 900-906.

22. Wicker LS, Clark J, Fraser HI et all. Type 1 diabetes genes and pathways shared by humans and NOD mice. Journal of Autoimmunity 2005; 25: 29-33.

23. Lally FJ, Ratcliff H, Bone AJ. Apoptosis and disease progression in the spontaneosly diabetic $\mathrm{BB} / \mathrm{S}$ rat. Diabetologia 2001; 44: 320-324.

24. Bortel R, Waite DJ, Whalen BJ, Todd D, Leif JH, Lesma E et all. Levels of Art2+ cells but not soluble Art 2 protein corelate with expression of autoimune diabetes in the BB rat. Autoimmunity 2001; 33: 199-211.

25. Wallis RH, Wang K. Type 1 Diabetes in the BB rat: A Polygenic Disease. Diabetes 2009; 58(4): 1077-11.

26. Surwit RS, Kuhn CM, Cochrane C, McCubbin JA, Feinglos MN. Diet-induced type 2 diabetes in C57BL/6J mice. Diabetes 1988; 37: 1163-1167.

27. Rebuffe-Scrive M, Surwit RS, Feinglos MN et al. Regional fat distribution and metabolism in a new mouse model (C57BL/6J) of non-insulin-dependent diabetes mellitus. Metabolism 1993; 42: 1405-1409.

28. Winzell MS, Ahren B. The high-fat diet-fed mouse A model for studying mechanisms and treatment of impared glucose tolerance and type 2 diabetes. Diabetes 2004; 53(3): S215-S219.

29. Parekh PI, Petro AE, Tiller JM et al. Reversal of dietinduced obesity and diabetes in C57BL/6J mice. Metabolism 1998; 47: 1089-1096.

30. Shimabukuro M, Zhou YT, Moshe L, Unger RH. Fatty acid-induced $\beta$ cell apoptosis: a link between obesity and diabetes. Proc Natl Acad Sci USA 1998; 95: 2498-502.

31. Hull RL, Kodama K, Utzschneider KM, Carr DB, Prigeon RL, Kahn SE. Dietary fat-induced obesity in mice results in beta cell hyperplasia but not increased insulin release: evidence for specificity of impaired beta cell adaptation. Diabetologia 2005; 48: 1350-1358.

32. Bisbis S, Bailbe D, Tormo MA, Picarel-Blanchot F, Derouet M, Simon J, Portha B. Insulin resistance in the GK rat: decreased receptor number but normal kinase activity in liver. Am J Physiol 1993; 265: E807-813.

33. Portha B, Giroix MH, Serradas P, Gangrenau MN, Movassat J, Rajas, F, Bailbe D, Plachot C, Mithieux G, \& Marie, JC. (2001). Beta-cell function and viability in the spontaneously diabetic GK rat: information from the GK/Par colony. Diabetes 2001; 50: S89-93.

34. Ostenson CG, Khan A, Abdel-Halim SM, Guenifi A, Suzuki K, Goto Y, Efendic S. Abnormal insulin secretion and glucose metabolism in pancreatic islets from the spontaneously diabetic GK rat. Diabetologia $1993 ; 36: 3-8$.

35. Alvarez, C, Bailbe D, Picarel-Blanchot F, Bertin E, Pascual-Leone AM, Portha B. Effect of early dietary restriction on insulin action and secretion in the GK rat, a spontaneous model of NIDDM. Am J Physiol Endocrinol Metab 2000; 278 : E1097-103.

36. Guenifi A, Abdel-Halmi SM, Hoog A, Falkmer S, Ostenson CG. Preserved beta-cell density in the endocrine pancreas of young, spontaneously diabetic GotoKakizaki (GK) rats. Pancreas 1995; 10: 148-153.

37. Matsuoka T, Kajimoto Y, Watada H, Umayahara Y, Kubota M, Kawamori R, Yamasaki Y, Kamada T. Expression of CD38 gene, but not of mitochondrial glycerol3-phosphate dehydrogenase, is impaired in pancreatic islets of GK rats. Biochem Biophys Res Commun 1995; 214: 239-246.

38. Ohneda M, Johnson JH, Inman LR, Chen L, Suzuki K, Goto Y, Alam T, Ravazzola M, Ocri L, Unger RH. GLUT2 expression and function in the beta-cells of GK rats with NIDDM. Dissociation between reductions in glucose transport and glucose-stimulated insulin secretion. Diabetes 1993; 42: 1065-1072.

39. Homo-Delarche F, Calderari S, Irminder JC, Gangnerau MN, Coulaud J, Rickenbach K, Dolz M, Halban P, Portha B. Islet inflammation and fibrosis in a spontaneous model of type 2 the GK rat. Diabetes 2006; 55: 1625-1633. 
40.Ehses JA, Lacraz G, Giroix MH, Schmidlin F, Coulaud J, Kassis N, Irminger JC, Kergoat M, Portha B, Homo-Delarche F, Donath MY. IL-1 antagonism reduces hyperglycemia and tissue inflammation in the type 2 diabetic GK rat. PNAS 2009; 106: 13998-14003.

41. Peterson RG, Shaw WN, Neel MA, Little LA, Eichberg J. (1990). Zucker diabetic fatty rat as a model for non-insulin dependent diabetes mellitus. ILAR J 1990; 32: 16-19.

42. Coresttis JP, Sparks, JD, Peterson, RG, Smith, RL, \& Sparks, CE. Effect of dietary fat on the development of non-insulin dependent diabetes mellitus in obese Zucker diabetic fatty male and female rats. Atherosclerosis 1999; 148: 231-41.

43. Lee Y, Hirose H, Zhou YT, Esser V, McGarry JD, Unger $\mathrm{RH}$. Increased lipogenic capacity of the islets of obese rats: a role in the pathogenesis of NIDDM. Diabetes 1997; 46: 408-13.

44. Erdely A, Freshour G, Maddox, D, Olson, J, Samsell L, Baylis C. Renal disease in rats with type 2 diabetes is associated with decreased renal nitric oxide production. Diabetologia 2004; 47: 1672-6.

45. Finegood DT, McArthur, MD, Kojwang D, Thomas, MJ, Topp BG, Leonard, T, Buckingham RE. $\beta$-Cell mass dynamics in Zucker diabetic fatty rats. Rosiglitazone prevents the rise in net cell death. Diabetes 2001; 50: 1021-9.

46. MacDonald MJ, Tang J, Polonsky KS. Low mitochondrial glycerol phosphate carboxylase in pancreatic islets of Zucker diabetic fatty rats. Diabetes 1996; 45: 1326-1330.

47. Kawano K, Hirashima T, Mori S, Saitoh Y, Kurosumi M, Natori T. Spontaneous long-term hyperglycaemic rat with diabetic complications Otsuka Long-Evans Tokushima Fatty (OLETF) strain. Diabetes 1992; 41: 1422-8.

48. Moran TH, Bi S. Hyperphagia and obesity of OLETF rats lacking CCK1 receptors: developmental aspects. Dev Psychobiol 2006; 48: 360-7.

49. Jia D, Taguchi, M, Otsuki M. (2005). Synthetic protease inhibitor camostat prevents and reverses dyslipidemia insulin secretory defects, and histological abnormalities of the pancreas in genetically obese and diabetic rats. Metabolism 2005; 54: 619-27.

50. Lewandowski PA, Cameron-Smith D, Jackson CJ, Kultys ER, Collier GR. The role of lipogenesis in the development of obesity and diabetes in Israeli sand rats (Psammomys obesus). J Nutr 1998; 128: 1984-8.

51. Bar-On H, Ben-Sasson R, Ziv E, Arar N, Shafrir E. Irreversibility of nutritionally induced NIDDM in Psammomys obesus is related to beta-cell apoptosis. Pancreas 1999; 18: 259-265.

52. Kaiser N, Yuli M, Uckaya G, Oprescu A, Berthault MF, Kargar C, Donath M, Erol C, Ktorza A. Dynamic changes in $\beta$-cell mass and pancreatic insulin during the evolution of nutrition-dependent diabetes in Psammomys obesus. Impact of glycemic control. Diabetes 2005b; 54: 138-145.
53. Plum L, Wunderlich FT, Baudler S, Krone W, Bruning JC. Transgenic and Knockout Mice in Diabetes Research: Novel Insights into Pathophysiology, Limitations, and Perspectives. Physiology 2005; 20(3): 152-161.

54. Accili D, Drago J, Lee EJ, Johnson MD, Cool MH, Salvatore P, Asico LD, Jose PA, Taylor SI, Westphal H. Early neonatal death in mice homozygous for a null allele of the insulin receptor gene. Nat Genet 1996; 12: 106-109.

55. Abe H, Yamada N, Kamata K, Kuwaki T, Shimada M, Osuga J, Shionoiri F, Yahagi N, Kadowaki T, Tamemoto H, Ishibashi S, Yazaki Y, Makuuchi M. Hypertension, hypertriglyceridemia, and impaired endothelium-dependent vascular relaxation in mice lacking insulin receptor substrate-1. J Clin Invest 1998; 101: 1784-1788.

56. Previs SF, Withers DJ, Ren JM, White MF, Shulman GI. Contrasting effects of IRS-1 versus IRS-2 gene disruption on carbohydrate and lipid metabolism in vivo. J Biol Chem 2000; 275: 38990-38994.

57. Laustsen PG, Michael MD, Crute BE, Cohen SE, Ueki K, Kulkarni RN, Keller SR, Lienhard GE, and Kahn CR. Lipoatrophic diabetes in Irs1(-/-)/Irs3(-/-) double knockout mice. Genes Dev 2002; 16: 3213-3222.

58. Bruning JC, Winnay J, Bonner-Weir S, Taylor SI, Accili D, and Kahn CR. Development of a novel polygenic model of NIDDM in mice heterozygous for IR and IRS-1 null alleles. Cell 1997; 88: 561-572.

59. Grupe A, Hutlgren B, Ma YH, Bauer M, Stewart TA. Transgenic knockouts reveal a critical requirement for pancreatic P cell glucokinase in maintaining glucose homeostasis. Cell 1995; 83- 69-78.

60. Katz EB, Stenbit AE, Hatton K, DePinho R, and Charron MJ. Cardiac and adipose tissue abnormalities but not diabetes in mice deficient in GLUT4. Nature 1995; 377: 151-155.

61. Kubota N, Terauchi Y, Miki H, Tamemoto H, Yamauchi T, Komeda K, Satoh S, Nakano R, Ishii C, Sugiyama T, Eto K, Tsubamoto Y, Okuno A, Murakami K, Sekihara H, Hasegawa G, Naito M, Toyoshima Y, Tanaka S, Shiota K, Kitamura T, Fujita T, Ezaki O, Aizawa S, Kadowaki T. PPAR mediates high-fat diet-induced adipocyte hypertrophy and insulin resistance. Mol Cell 1999; 4: 597-609.

62. Zhang J, Fu M, Cui T, Xiong C, Xu K, Zhong W, Xiao Y, Floyd D, Liang J, Li E, Song Q, Chen YE. Selective disruption of PPAR 2 impairs the development of adipose tissue and insulin sensitivity. Proc Natl Acad Sci USA 2004; 101: 10703-10708.

63. Djouadi F, Weinheimer CJ, Saffitz JE, Pitchford C, Bastin J, Gonzalez FJ, and Kelly DP. A gender-related defect in lipid metabolism and glucose homeostasis in peroxisome proliferator-activated receptor -deficient mice. J Clin Invest 1998; 102: 1083-1091.

64. Butler, AE, Jang, J, Gurlo T, Carty MD, Soeller WC, \& Butler, PC. Diabetes due to a progressive defect in $\beta$-cell mass in rats transgenic for human islet amyloid polypeptide (HIP rat). Diabetes 2004; 53: 1509-1516. 